\title{
A New, Atypical Case of Cobalamin F Disorder Diagnosed by Whole Exome Sequencing
}

\author{
Panayiotis Constantinou $^{\mathrm{a}}$ Mariella D'Alessandro $^{\mathrm{a}}$ Paul Lochhead $^{\mathrm{a}}$ \\ Shalaka Samant ${ }^{b}$ W. Michael Bisset ${ }^{c}$ Catherine Hauptfleisch ${ }^{d}$ John Dean ${ }^{a}$ \\ Deciphering Developmental Disorders Study Group

\begin{abstract}
a North of Scotland Regional Genetics Service, Ashgrove House, ${ }^{b}$ Molecular Genetics Department, University of Aberdeen, 'Department of Paediatric Gastroenterology, Royal Aberdeen Children's Hospital, and d Department of Neonatology, Aberdeen
\end{abstract} \\ Maternity Hospital, Foresterhill, UK
}

\section{Established Facts}

- Cobalamin F disorder is caused by homozygous or compound heterozygous mutation in LMBRD1.

- Typical presenting features include poor growth, developmental delay and macrocytic anaemia with neutropaenia and thrombocytopaenia.

\section{Novel Insights}

- Cleft palate, renal agenesis, prominent metopic suture and neonatal liver dysfunction may be features of the disorder.

- Whole exome sequencing is a non-invasive route to diagnosis in rare developmental disorders where neonatal clinical and biochemical findings are inconclusive.

\section{Key Words}

Cobalamin F disorder . LMBRD1 mutation

\begin{abstract}
Cobalamin F (cblF) disorder, caused by homozygous or compound heterozygous mutations in the LMBRD1 gene, is a recognised cause of developmental delay, pancytopaenia and failure to thrive which may present in the neonatal period. A handful of cases have been reported in the medical literature. We report a new case, diagnosed at the age of 6 years through whole exome sequencing, with atypical features including prominent metopic suture, cleft palate, unilateral renal agenesis and liver abnormalities, which broaden the phenotypic spectrum.

(c) 2015 The Author(s)

Published by S. Karger AG, Basel
\end{abstract}

Disorders of intracellular cobalamin metabolism include methylmalonic acidaemia and homocystinuria. These inborn errors of metabolism can manifest with dysmorphism, developmental delay, encephalopathy and megaloblastic anaemia. Cobalamin $\mathrm{F}(\mathrm{cblF})$ is a cofactor in the vitamin $B_{12}$ metabolism pathway, encoded by the LMBRD1 gene on chromosome $6 \mathrm{q} 13$ [Rutsch et al., 2009]. Deficiency is inherited in an autosomal recessive fashion, characteristically associated with intrauterine growth restriction, failure to thrive, congenital heart disease, developmental delay, macrocytic anaemia, neutropaenia, thrombocytopaenia, hyperhomocysteinaemia and methylmalonic aciduria [Alfadhel et al., 2011]. It is usually diagnosed through urine organic acid and plasma amino acid analysis. Molecular analysis of $L M B R D 1$ can be used to confirm the genetic basis of the disease.

\begin{tabular}{ll}
\hline KARGER 125/s & $\begin{array}{l}\text { ( } 2015 \text { The Author(s) } \\
\text { Published by S. Karger AG, Basel } \\
\text { 1661-8769/15/0065-0254\$0/0 }\end{array}$ \\
E-Mail karger@karger.com & $\begin{array}{l}\text { Karger } \\
\text { www.karger.com/msy }\end{array}$ \\
& $\begin{array}{l}\text { This article is licensed under the Creative Commons Attribution } 4.0 \\
\text { International License (CC BY) (http://www.karger.com/Services/ } \\
\text { OpenAccessLicense). Usage, derivative works and distribution are } \\
\text { permitted provided that proper credit is given to the author and the }\end{array}$
\end{tabular}



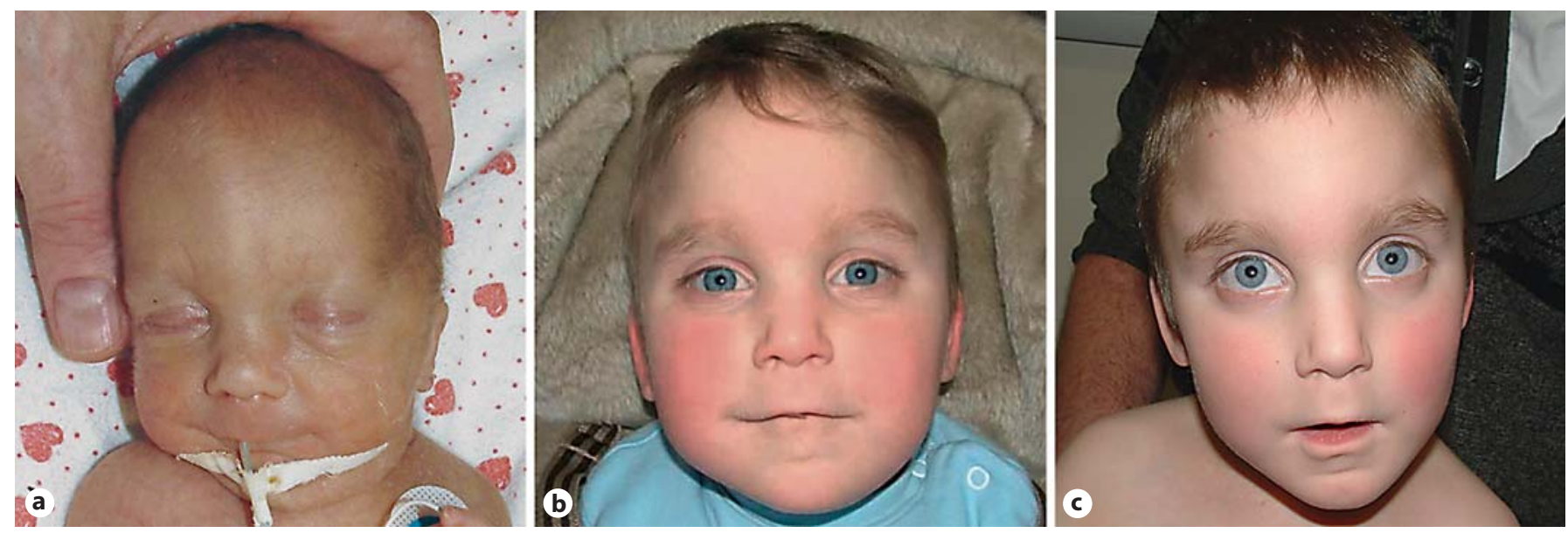

Fig. 1. Frontal view of the facial characteristics. a Shortly after birth. b At age 3 years. c At age 6 years.

We present a 6-year-old child with an atypical presentation of cblF disorder, diagnosed by whole exome sequencing (WES).

\section{Case Report}

The proband was referred to our genetic service at the age of 1 month due to cleft palate, thrombocytopaenia and renal agenesis. The pregnancy history was notable for pregnancy-associated hypertension, for which the mother was managed with methyldopa. Prenatal ultrasonography demonstrated limb shortening and decreased liquor volumes. Delivery was by emergency lower segment Caesarian section at 32 weeks' gestation for fetal distress. APGAR scores were 8 at $1 \mathrm{~min}$ and 9 at $5 \mathrm{~min}$ after delivery. Growth parameters at birth were: weight $1,100 \mathrm{~g}$ (1.4th centile for gestational age), length $34 \mathrm{~cm}(<0.4$ th centile), and head circumference $28 \mathrm{~cm}$ (8th centile). Physical examination revealed a prominent metopic ridge, midline cleft soft palate, low-set ears, broad nasal tip, micrognathia and undescended testes with a right-sided inguinal hernia (fig. 1). Ophthalmological assessment revealed abnormal retinal streaking pigmentation. Imaging demonstrated thoraco-lumbar scoliosis and right renal agenesis. A small patent ductus arteriosus with mild peripheral pulmonary artery stenosis was identified, which resolved spontaneously by the age of 3 years. He had feeding difficulties and required parenteral nutrition during the first 6-8 weeks of life. Thrombocytopaenia and neutropaenia were evident, initially attributed to sepsis and treated with antibiotics. A bone marrow examination was normal apart from neutrophil maturation arrest at the metamyelocyte stage, which responded to granulocyte colony stimulating factor. He also had persistent conjugated hyperbilirubinaemia. A liver biopsy at 3 months of age revealed a paucity of bile ducts, but molecular analysis of JAG1 for suspected Alagille syndrome was normal. Biochemical investigation at 6 weeks of age revealed a non-specific aminoaciduria with a slightly increased plasma homocysteine, in addition to peaks of methyl- malonic acid, p-hydroxyphenyllactic acid and p-hydroxyphenylpyruvic acid on organic acid analysis. These findings were attributed to hepatic insult and inadequate vitamin supplementation while on parenteral nutrition. A single dose of intramuscular hydroxocobalamin was given and folate supplementation was instituted by tube feeding, continuing until the age of 3 years. Repeat biochemical studies at 2 and 3 months of age demonstrated an improvement in the biochemical profile (table 1). At this time, care was transferred to another team and permanent enteral feeding was commenced by percutaneous gastrostomy. As the initial blood abnormalities appeared to have resolved, further diagnostic investigation was not pursued at this stage.

Severe global developmental delay was apparent on follow-up. Unaided sitting was first recorded at around 3 years of age, and walking, with a wide-based gait, was first recorded at around 6 years of age. A mild intention tremor was noted from the age of 4 years. There was no speech on the last review at age 10, but he also had bilateral sensorineural deafness and communicated using some simple Makaton signing. He had proportional short stature with a height of $116 \mathrm{~cm}(<0.4$ th centile), weight $23.8 \mathrm{~kg}$ (5th centile), and a head circumference of $49 \mathrm{~cm}(<0.4$ th centile).

Array comparative genomic hybridisation analysis (Nimblegen CGX array v1.0) was normal as was a standard karyotype. At 6 years of age, he was entered into the Deciphering Developmental Disorders Study and WES was performed [methods described in the Deciphering Developmental Disorders Study, 2015]. This demonstrated a homozygous pathogenic mutation c.1056delG; p.Leu352fs*18 in the LMBRD1 gene, which was subsequently confirmed by Sanger sequencing. Heterozygosity for this mutation was confirmed in both parents. No other potentially pathogenic variants were detected in any known development gene, no regional homozygosity was detected in the exome data using BCFtools v1.0, and no evidence of isodisomy was seen. After establishing the molecular diagnosis, biochemical studies were performed, revealing modestly elevated plasma homocystine and urine methylmalonic acid levels. Regular intramuscular hydroxocobalamin supplementation was instituted at this time, resulting in normalisation of the 
Table 1. Biochemical findings in the proband

\begin{tabular}{|c|c|c|c|c|c|c|c|c|c|}
\hline \multirow[t]{2}{*}{ Age } & \multicolumn{6}{|l|}{ Plasma } & \multicolumn{2}{|l|}{ Urine } & \multirow[t]{2}{*}{ Comments } \\
\hline & $\begin{array}{l}\text { MMA } \\
(<10 \mu \mathrm{mol} / \mathrm{mmol} \\
\text { creatinine })\end{array}$ & $\begin{array}{l}\text { cysteine } \\
(20-80 \mu \mathrm{M})\end{array}$ & $\begin{array}{l}\text { methionine } \\
(10-60 \mu \mathrm{M})\end{array}$ & $\begin{array}{l}\text { homocystine } \\
(0-1 \mu \mathrm{M})\end{array}$ & $\begin{array}{l}\text { homocysteine } \\
(0-20 \mu \mathrm{M})\end{array}$ & $\begin{array}{l}\mathrm{B}_{12} \\
(200-700 \mathrm{ng} / \mathrm{l})\end{array}$ & $\begin{array}{l}\text { MMA } \\
(<10 \mu \mathrm{mol} / \mathrm{mmol} \\
\text { creatinine })\end{array}$ & $\begin{array}{l}\text { homocystine } \\
(<1 \mu \mathrm{mol} / \mathrm{mmol} \\
\text { creatinine })\end{array}$ & \\
\hline $6 \mathrm{w}$ & & & & 29 & & & 530 & & $\begin{array}{l}\text { modestly elevated plas- } \\
\text { ma phenylalanine and } \\
\text { tyrosine }\end{array}$ \\
\hline $2 \mathrm{mo}$ & & & & 11 & 170 & $>1,000$ & 304 & 96 & after supplementation \\
\hline $3 \mathrm{mo}$ & & & & 4 & 107 & & 55 & 31 & \\
\hline 7.75 ys & & & 28 & $<1$ & 33 & 202 & 30 & 5 & at molecular diagnosis \\
\hline 8.1 ys & 4 & 39 & 29 & 2 & 11 & $>2,000$ & & 16 & $\begin{array}{l}\text { after instituting } \\
\text { hydroxocobalamin }\end{array}$ \\
\hline 8.5 ys & 12 & 40 & 34 & $<1$ & 13 & & & 13 & \\
\hline 8.75 ys & 5 & 34 & 34 & 1 & 13 & & & 12 & \\
\hline 9 ys & $<1$ & 45 & 20 & $<1$ & 14 & & $<1$ & 2 & \\
\hline 9.5 ys & & 40 & 19 & $<1$ & 17 & & & & \\
\hline 9.8 ys & $<1$ & 42 & 29 & 1 & 14 & & & 12 & \\
\hline
\end{tabular}

MMA = Methylmalonic acidaemia; $\mathrm{mo}=$ months; $\mathrm{w}=$ weeks; $\mathrm{ys}=$ years. Values in bold print represent abnormal results.

Fig. 2. Growth parameters in the proband before and after institution of intramuscular (IM) hydroxocobalamin.

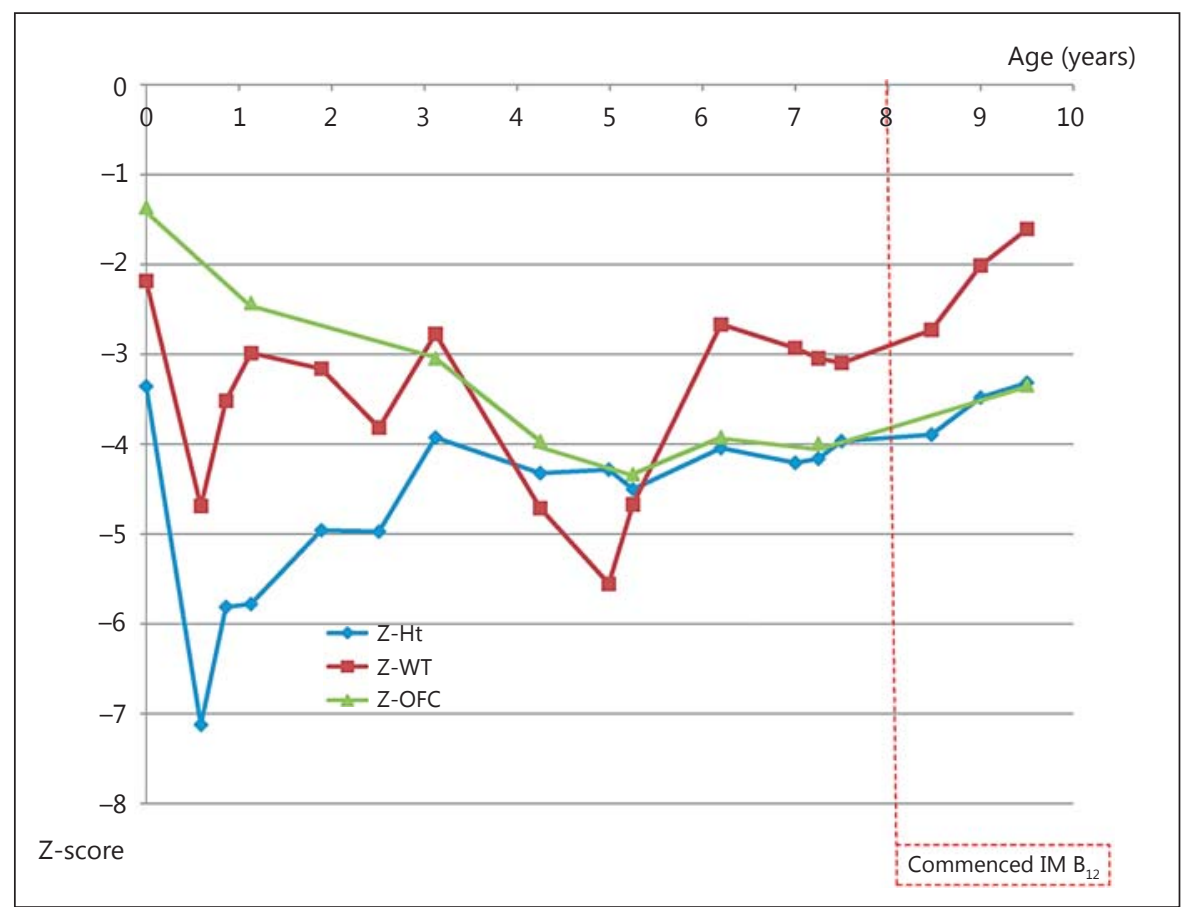

biochemical findings (table 1). There has been no change in his developmental status in the 2 years since starting therapy although growth parameters have improved slightly (fig. 2).

\section{Discussion}

We present a new case of cblF disorder, presenting in an atypical manner with a prominent metopic suture, cleft palate, unilateral renal agenesis, feeding difficulties, and early liver abnormalities, which was diagnosed late by the use of WES. To date, a total of 15 cases have been reported in the literature [Rosenblatt et al., 1986; Shih et al., 1989; MacDonald et al., 1992; Wong et al., 1992; Waggoner et al., 1998; Rutsch et al., 2009; Gailus et al., 2010; Miousse et al., 2011; Oladipo et al., 2011] in addition to a recent case of combined $\mathrm{cblF} / \mathrm{cblG}$ disorder suggestive of digenic inheritance [Farwell Gonzalez et al., 2015]. The typical clinical phenotype of cblF disorder is failure to 
Table 2. Clinical features of cblF disorder described in the literature compared to features seen in our patient

\begin{tabular}{|c|c|c|}
\hline Features & $\begin{array}{l}\text { Number of } \\
\text { affected } \\
\text { patients }\end{array}$ & Our patient \\
\hline Developmental delay & 7 & + \\
\hline Failure to thrive & 7 & + \\
\hline Haematological features & 6 & + \\
\hline Congenital cardiac anomalies & 6 & + \\
\hline Small for gestational age & 6 & + \\
\hline Stomatitis +/- glossitis & 5 & \\
\hline Gastric upset & 3 & \\
\hline Dental anomalies & 3 & \\
\hline Feeding difficulties & 3 & + \\
\hline Microcephaly & 2 & + \\
\hline Seizures & 2 & \\
\hline Hypotonia & 2 & \\
\hline Torticollis & 1 & \\
\hline Pes equinovarus & 1 & \\
\hline Tracheoesophageal fistula & 1 & \\
\hline Intrauterine growth retardation & 1 & + \\
\hline Arthritis & 1 & \\
\hline Hepatic involvement & 1 & + \\
\hline Rash & 1 & \\
\hline Recurrent infection & 1 & \\
\hline Facial dysmorphism & 1 & + \\
\hline Recurrent apnoea & 1 & \\
\hline Encephalopathy & 1 & \\
\hline Cleft palate & 0 & + \\
\hline Unilateral renal agenesis & 0 & + \\
\hline
\end{tabular}

thrive and feeding difficulties, developmental delay and haematological features including megaloblastic anaemia, neutropaenia and thrombocytopaenia (table 2). All but one of the previously described cases carry the c.1056delG; p.Leu352fs* 18 . Of the 7 cases that are homozygous for this mutation, the majority displayed developmental delay, haematological findings and failure to thrive, though their phenotypes were otherwise variable. Hepatic involvement and prominent metopic suture or dysmorphism as found in our patient have been infrequently described [Oladipo et al., 2011, Rutsch et al., 2009]. Cleft palate has not been described previously in cblF deficiency, but has been reported with other disorders of vitamin $\mathrm{B}_{12}$ and folic acid metabolism [Natsume et al., 1998; Weingärtner et al., 2007; Boyles et al., 2008]. Renal tubulointerstitial dysfunction has been described in disorders of cobalamin metabolism [Morath et al., 2013] as has reduced renal growth [Kruszka et al., 2013]. Renal agenesis has, however, not been described.
Early institution of intramuscular hydroxocobalamin corrects the biochemical abnormalities of hyperhomocysteinaemia and methylmalonic acidaemia and appears to limit the severity of cognitive and neurological impairment [Alfadhel et al., 2011]. Although late institution of intramuscular hydroxocobalamin corrected the biochemical profile in our patient, there has unfortunately been no effect on the severity of the patient's developmental delay, though there appears to be a trend of improvement in growth paramaters. The initial biochemical abnormalities might have guided towards the diagnosis, but were instead attributed to the effects of parenteral nutrition as they were partly corrected with modification of the regimen. In retrospect, the resolution of the haematological abnormalities also coincided with the institution of enteral nutrition and vitamin supplementation, but did not recur when vitamin supplementation was subsequently reduced. By virtue of his continued gastrostomy feeding, some vitamin supplementation has continued throughout his childhood, and this may explain why the usual haematological and biochemical features have not re-appeared. It should be noted that both prematurity and parenteral nutrition are associated with hepatic biochemical abnormalities [Schutzman et al., 2008]. We cannot be certain how much the cblF disorder contributed to the hepatic dysfunction in this case. This study supports the utility of a genomic testing approach to make an early diagnosis for neonates with a complex clinical presentation, as has been previously suggested elsewhere [Saunders et al., 2012].

The first 1,133 family trios from the Deciphering Developmental Disorders Study have now been reported, with an overall diagnostic yield of 27\% [Deciphering Developmental Disorders Study, 2014; Wright et al., 2015]. One of the outcomes from the initial analysis has been the broadening of the phenotypic spectrum of previously well-described monogenic developmental disorders. The importance of high-quality or deep clinical phenotyping of rare diseases in the genomic era cannot be underestimated. It will improve our understanding of the natural history of these disorders, and may reveal findings that will affect clinical management. As in this case, it may reveal new genotype-phenotype correlations, giving a better understanding of the molecular bases of developmental disorders and hopefully facilitating the development of targeted therapies.

In summary, this new case of cblF deficiency, diagnosed via WES, broadens the phenotypic spectrum of the condition. It is likely that the incorporation of WES into clinical practice will highlight wider phenotypic variability in previously defined disorders. 


\section{Acknowledgements}

The Deciphering Developmental Disorders Study presents independent research commissioned by the Health Innovation Challenge Fund (HICF-1009-003), a parallel funding partnership between the Wellcome Trust and the Department of Health, and the Wellcome Trust Sanger Institute (WT098051). The views expressed in this publication are those of the author(s) and not necessarily those of the Wellcome Trust or the Department of Health. The research team acknowledges the support of the National Institute for Health Research, through the Comprehensive Clinical Research Network.

\section{Statement of Ethics}

The study has UK Research Ethics Committee approval (10/ H0305/83, granted by the Cambridge South REC, and GEN/284/12 granted by the Republic of Ireland REC).

\section{Disclosure Statement}

The authors have no conflicts of interest to declare.

\section{References}

Alfadhel M, Lillquist YP, Davis C, Junker AK, Miousse IR, Watkins D, Rosenblatt DS: Novel Stockler-Ipsiroglu S: Eighteen-year follow-up of a patient with cobalamin $\mathrm{F}$ disease $(\mathrm{cblF})$ : report and review. Am J Med Genet A 155A:2571-2577 (2011).

Boyles AL, Wilcox AJ, Taylor JA, Meyer K, Fredriksen A, et al: Folate and one-carbon metabolism gene polymorphisms and their associations with oral facial clefts. Am J Med Genet A 146A:440-449 (2008).

Deciphering Developmental Disorders Study: Large-scale discovery of novel genetic causes of developmental disorders. Nature 519:223228 (2015).

Farwell Gonzalez KD, Li X, Lu HM, Lu H, Pellegrino JE, et al: Diagnostic exome sequencing and tailored bioinformatics of the parents of a deceased child with cobalamin deficiency suggests digenic inheritance of the MTR and LMBRD1 genes. JIMD Rep 15:29-37 (2015).

Gailus S, Suormala T, Malerczyk-Aktas AG, Toliat MR, Wittkampf T, et al: A novel mutation in $L M B R D 1$ causes the cblF defect of vitamin $\mathrm{B}_{12}$ metabolism in a Turkish patient. J Inherit Metab Dis 33:17-24 (2010).

-Kruszka PS, Manoli I, Sloan JL, Kopp JB, Venditti CP: Renal growth in isolated methylmalonic aciduria. Genet Med 15:990-996 (2013).

MacDonald MR, Wiltse HE, Bever JL, Rosenblatt DS: Clinical heterogeneity in two patients with cblF disease. Am J Hum Genet 51:A353 (1992). splice site mutations and a large deletion in three patients with the cblF inborn error of vitamin $\mathrm{B}_{12}$ metabolism. Mol Genet Metab 102:505-507 (2011)

Morath MA, Hörster F, Sauer SW: Renal dysfunction in methylmalonic acidurias: review for the pediatric nephrologist. Pediatr Nephrol 28:227-235 (2013).

Natsume N, Nagatsu Y, Kawai T: Direct effect of vitamins at the time of palatal fusion. Plast Reconstr Surg 102:2512-2513 (1998).

Oladipo O, Rosenblatt DS, Watkins D, Miousse IR, Sprietsma L, et al: Cobalamin F disease detected by newborn screening and follow-up on a 14-year-old patient. Pediatrics 128: e1636-1640 (2011).

Rosenblatt DS, Laframboise R, Pichette J, Langevin $\mathrm{P}$, Cooper BA, Costa T: New disorder of vitamin $\mathrm{B}_{12}$ metabolism (cobalamin $\mathrm{F}$ ) presenting as methylmalonic aciduria. Pediatrics 78:51-54 (1986).

Rutsch F, Gailus S, Miousse IR, Suormala T, Sagné $\mathrm{C}$, et al: Identification of a putative lysosomal cobalamin exporter altered in the cblF defect of vitamin $\mathrm{B}_{12}$ metabolism. Nat Genet 41: 234-239 (2009).
Saunders CJ, Miller NA, Soden SE, Dinwiddie DL, Noll A, et al: Rapid whole-genome sequencing for genetic disease diagnosis in neonatal intensive care units. Sci Transl Med 4: 154ra135 (2012).

Schutzman DL, Porat R, Salvador A, Janeczko M: Neonatal nutrition: a brief review. World J Pediatr 4:248-253 (2008).

-Shih VE, Axel SM, Tewksbury JC, Watkins D, Cooper BA, Rosenblatt DS: Defective lysosomal release of vitamin $\mathrm{B}_{12}$ (cb1F): a hereditary cobalamin metabolic disorder associated with sudden death. Am J Med Genet 33:555563 (1989).

-Waggoner DJ, Ueda K, Mantia C, Dowton SB: Methlymalonic aciduria (cblF): case report and response to therapy. Am J Med Genet 79: 373-375 (1998).

$>$ Weingärtner J, Lotz K, Fanghänel J, Gedrange T, Bienengräber V, Proff P: Induction and prevention of cleft lip, alveolus and palate and neural tube defects with special consideration of $\mathrm{B}$ vitamins and the methylation cycle. J Orofac Orthop 68:266-277 (2007).

Wong TK, Rosenblatt DS, Applegarth DA: Diagnosis and treatment of a child with cblF disease. Clin Invest Med 15:A111 (1992).

$\checkmark$ Wright CF, Fitzgerald TW, Jones WD, Clayton S, McRae JF, et al: Genetic diagnosis of developmental disorders in the DDD study: a scalable analysis of genome-wide research data. Lancet 385:1305-1314 (2015). 